JINOTEP Vol (6) No 1 (2019): 45-50
JINOTEP (Jurnal Inovasi Teknologi Pembelajaran):
Kajian dan Riset Dalam Teknologi Pembelajaran
http://journal2.um.ac.id/index.php/jinotep/index

\title{
PENGEMBANGAN MEDIA VIDEO PEMBELAJARAN UNTUK MENINGKATKAN PEMAHAMAN MATERI GAYA KELA IV DI SDN SUKOIBER 1 JOMBANG
}

\author{
Amilia Sholikh Hidayati, Eka Pramono Adi, Henry Praherdhiono \\ Jurusan Teknologi Pendidikan, Fakultas Ilmu Pendidikan, Universitas Negeri Malang
}

\section{Article History \\ Received:April 25, 2019 \\ Accepted:May 21, 2019 \\ Published: July 16, 2019}

\section{Keywords}

Pengembangan, Media Video Pembelajaran, Pemahaman, IPA

\begin{abstract}
Abstrak
Peneltian ini berfokus menghasilkan media video pemebalajaran untuk meningkatkan pemahaman materi gaya. Prosedur pengembangan media video pembelajaran menggunakan model ADDIE dengan tahapan analysis, design, development, implementation, dan evaluation. Hasil validasi oleh ahli media diperoleh hasil keseluruhan $93.7 \%$ yang berdasarkan kriteria media valid dan layak digunakan dalam proses pembelajaran. Hasil validasi oleh ahli materi diperoleh hasil keseluruhan $98.7 \%$ yang berdasarkan kriteria media valid dan layak digunakan dalam proses pembelajaran. Hasil uji coba pada siswa kelas IV SDN Sukoiber 1 diperoleh hasil keseluruhan $96.4 \%$ yang berdasarkan kriteria media valid dan layak digunakan dalam proses pembelajaran. Hasil pre-test dan post-test siswa terdapat peningkatan nilai sebesar $86,95 \%$ yang berdasarkan kriteria yang telah ditetapkan media video pembelajaran termasuk dalam kriteria ekertif digunakan dalam proses pembelajaran. Hasil peningkatan pemahaman materi Gaya siswa sebesar 30\% dan berdasarkan data uji N-Gain diperoleh nilai gain sebesar 0, 71. Berdasarkan kriteria yang telah ditetapkan dapat disimpulkan bahwa peningkatan pemahaman materi Gaya siswa kelas IV tergolong Tinggi.
\end{abstract}

\begin{abstract}
This research is focused on produce a media video learning for increase understanding force material. Procedure developing media video learning used ADDIE model with the stages analysis, design, development, implementation, and evaluation. The result of the validation by media expert obtained all result $93.7 \%$ based on the criteria media validation and worth used in the learning process. The research of the validation by material expert obtained all result $98.7 \%$ base on the criteria media validation and worth used in the learning process. The result of the trial to Elementary student Sukoiber 1 in the fourth class got totally result 96.4\% based on the criteria media validation and worth used in the learning process. The result of student pre-test and post-test there is an increase in the value of $86.95 \%$ base on the criteria that has been set media video learning include in the effective criteria used in the learning process. The result of an increase in understanding force material student for $30 \%$ and base on the data test $N$-Gain obtained value gain for 0,71. Base on the criteria has been set can be infer that an increase in understanding of the force material student fourth class is relatively high
\end{abstract}

Corresponding author :

Amilia Sholikh Hidayati

Jalan Semarang 5 Malang

E-mail: amilias.hidayati@gmail.com
2019 Universitas Negeri Malang p-ISSN 2406-8780 e-ISSN 2654-7953 


\section{PENDAHULUAN}

Lingkungan belajar dalam pendidikan formal akan memberikan kenyamanan kepada pengguna dalam belajar dan pembelajaran (Praherdhiono, 2014). Media pembelajaran merupakan komponen lingkungan belajar memberikan sumbangan terhadap kemampuan pengguna dalam mengakses material pembelajaran secara demokratis (Praherdhiono, 2016).

Sekolah Dasar memerlukan lingkungan belajar yang mampu mengelola media pembelajaran. Sekolah Dasar merupakan jenjang pendidikan dasar yang diselenggarakan satuan pendidikan formal di Indonesia (Passe, 1999). Pendidikan yang ditempuh ketika Sekolah Dasar akan menjadi fondasi bagi proses belajar selanjutnya sehingga pembelajaran di tingkat Sekolah Dasar harus dilaksanakan dengan optimal. Sekolah dasar memberikan pembelajaran dasar seperti menulis, membaca, berpikir kritis serta kemampuan berkomunikasi sebagai bekal untuk jenjang pendidikan selanjutnya, Prastowo dalam (Akbar dkk., 2016). Proses pembelajaran memiliki komponenkomponen yang saling berhubungan, diantaranya: (1) siswa, (2) guru, (3) media pembelajaran, (4) metode pembelajaran, (5) tujuan pembelajaran, (6) sumber belajar, (7) sarana prasarana (8) lingkungan. Keberhasilan proses belajar dikatakan optimal apabila dalam semua komponen tersebut juga optimal salah satunya media pembelajaran.

Di era digital saat ini proses pembelajaran menggunakan teknologi komputer sudah dilakukan namum belum menyeluruh, khususnya di jenjang Sekolah Dasar. Pemanfaatannya dalam pendidikan misalanya media pembelajaran. Media bisa diartikan sebagai perantara, guru dapat menggunakan media untuk menyampaikan materi kepada siswa. Media sebagai alat penyalur informasi merupakan hal yang penting ketika proses pembelajaran (Abidin, 2017). Namun pemilihan media untuk pembelajaran perlu diimbangi dengan kesanggupan guru untuk memanfaatkannya. Video bisa dikatakan media yang familier bagi guru walaupun belum menggunakan media sama sekali. Peran video tidak lagi hanya dipandang sebagai sarana hiburan namun juga dapat berfungsi sebagai media pembelajaran (Fadhli, 2015). Riyana
(2007) menjelaskan bahwa media video pembelajaran merupakan media audio visual yang menyajikan pesan pembelajaran berupa konsep-konsep, prinsip-prinsip, prosedur serta teori aplikasi pengetahuan yang bisa membantu siswa memahami suatu materi pembelajaran.

Memahami merupakan tujuan pembelajaran ranah kognitif setelah mengingat, taksonomi bloom revisi Anderson dalam (Gunawan dan Palupi, 2016). Terdapat enam tingkatan dalam taksonomi Bloom, yaitu: (C1) mengingat, (C2) memahami, (C3) menerapkan, (C4) menganalisis, (C5) mengevaluasi dan (C6) mencipta. Kemampuan memahami merupakan kamampuan dasar yang penting dikuasai siswa untuk mencapai hasil belajar. Siswa tidak hanya mengingat tetapi juga memahami, oleh sabab itu pemahaman materi perlu dikuasai sejak Sekolah Dasar. Anak Sekolah Dasar berada pada periode perkembangan kognitif tahap operasional konkret (Ibda, 2015). Anak masih belajar dengan menggunakan objek konkret untuk mengembangkan intelektualnya. Mereka mulai sudah dapat memahami tentang menulis, berhitung dan berkorespondensi (mengubungkan antara bentuk dan isi) serta sudah mulai belajar berpikir secara abstrak namun masih sederhana (Desstya, 2014).

Ilmu Pengertahuan Alam merupakan kompetensi dasar pokok dalam kurikulum pembelajaran Sekolah Dasar di Indonesia. Salah satu tujuan IPA Sekolah Dasar mengembangkan pengetahuan serta pemahaman tentang konsep pembelajaran IPA yang dapat diterapkan dan dimanfaatkan di kehidupan sehari-hari. Pembelajaran IPA yang bermakna tidak hanya menghafal melainkan membutuhkan pemahaman konsep (Widiyatmoko dan Shimizu, 2018). Proses pembelajaran IPA harus diajarkan dengan semaksimal mungkin agar siswa bisa mememahami materi dan menjadi pengetahuan awal siswa untuk jenjang pendidikan selanjutnya.

Berdasarkan observasi di SDN Sukoiber 1 Jombang, menemukan beberapa hambatan dalam kegiatan belajar pada kompetensi dasar IPA kelas IV. Dari hasil pengamatan ketika guru mengajar, metode ceramah masih dilakukan sehingga siswa merasa bosan dikelas. Penjelasan materi oleh guru dari buku guru yang disediakan oleh sekolah. Ketika proses pembelajaran juga 
Hidayati - Pengembangan Media Video....

tidak terjadi timbal balik ketika guru bertanya kepada siswa.

Pada pembelajaran IPA kelas IV tema 7 Indahnya Keragaman di Negeriku subtema 1 Keragaman Suku Bangsa dan Agama di Negeriku materi Gaya merupakan materi yang membahas materi Gaya dan pemanfaatannya dalam kehidupan sehari-hari. Buku yang dijadikan bahan ajar hanya memberikan sedikit materi, sehingga berdampak pada kurangnya pemahaman siswa. Dari hambatan hasil observasi, penelitian ini mengembangkan media video pembelajaran yang dapat menunjang proses pembelajaran. Sekolah juga memiliki fasilitas LCD juga dapat mendukung video pembelajaran dalam proses pembelajaran.

Berdasarkan uraian diatas, maka tujuan penelitian ini adalah menghasilkan media video pembelajaran untuk meningkatkan pemahaman materi Gaya kelas IV di SDN Sukoiber 1 yang valid dan efektif digunakan dalam proses pembelajaran.

\section{METODE}

Penelitian pengembangan media video pembelajaran IPA materi Gaya ini menggunakan metode penelitian pengembangan (research and development). Model pengembangan yang digunakan adalah model ADDIE dengan tahapan, diantaranya analisis (analysis), desain (design), pengembangan (development), implementasi (implementation), dan evaluasi (evaluation).

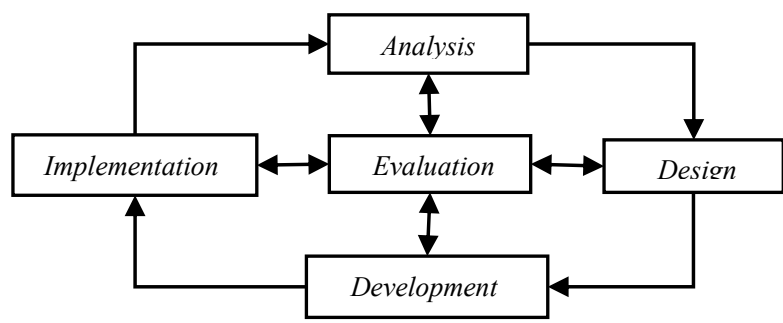

Gambar 1. Prosedur Pengembangan Model ADDIE Sumber: (Tegeh dkk., 2014)

\section{Analisis}

Tahap pertama adalah analisis. Kegiatan anlaisis meliputi analisis kerja, analisis karakteristik siswa dan analisis kebutuhan (Aceto dkk., 2014).
Analisis kerja

Hasil obeservasi yang sudah dilakukan diperoleh hasil metode ceramah masih digunakan guru dan hanya menggunakan buku guru sebagai bahan ajar dimana sedikit materi yang disajikan tidak dipahami siswa.

Analisis karakteristik siswa

Siswa kelas IV SDN Sukoiber 1 berjumlah 23 siswa. Siswa Sekolah Dasar usia 7-11 tahun tergolong dalam tahap berpikir operasional konkret dimana muali belajar bepikir abstrak namun masih sederhana.

Analisis Kebutuhan

Berdasarkan data dari analisis kerja dan dan karakteristik siswa yang diperoleh, pemahaman materi menjadi masalah utama perlu adanya media yang membuat pembelajaran menjadi menyenagkan dan dapat membantu meningkatkan pemahaman materi. Media tersebut diwujudakan dalam media video pembelajaran yang didalamnya memuat teks, gambar, audio dan animasi. Video pembelajaran dipilih karena mudah dioperasikan oleh guru dan dapat membantu menyajikan materi.

\section{Desain}

Tahap desain pengembang melakukan kegiatan penyusunan materi, perancangan produk dan menyusun alat evaluasi (Bonk dan Graham, 2012).

Materi yang akan disajikan dalam video pembelajaran adalah tema 7 indahnya keragaman di negeriku subtema 1 keragaman suku bangsa dan agama di negeriku pembelajaran ke 1 kompetensi dasar IPA materi tentang Gaya pada kelas IV Sekolah Dasar. Selanjutnya kegiatan perancangan produk meliputi pembuatan storyboard, pengumpulan gambar, merekam dubbing, dan membuat animasi.

Instrumen untuk mengukur kevalidan dan kualitas media video pembelajaran materi Gaya adalah angket. Angket diberikan kepada ahli media, ahli materi dan audiens (siswa). Sedangkan untuk mengukur efektivitas media dalam meningkatkan pemahaman siswa digunkaan instrumen tes hasil belajar berupa pre-test dan post-test.

\section{Pengembangan}

Tahap pengembangan merupakan kegiatan produksi video dari storyboard yang telah 
dirancang. Software yang akan digunakan. Dalam produksi media video pembelajaran materi Gaya menggunakan adobe flash CS6 sebagai software utama dan adobe illustrator CS6 dan adobe audition CS6 sebagi software pendukung.

Tahap selanjutnya uji validaitas untuk mengetahui kevalidan media video pembelajaran. Validasi media dilakukan oleh ahli media dan ahli materi Ahli media yang dipilih adalah dosen Jurusan Teknologi Pendidikan dengan pendidikan akhir S2 dan memiliki keahlian tentang video pembelajaran. Ahli materi adalah guru pengajar yang memiliki pengalaman mengajar IPA dengan pendidikan akhir minimal S1.

\section{Penerapan}

Tahap penerapan dilakukan setelah media video pembelajaran materi sudah divalidasi oleh ahli media dan ahli materi. Selanjutnya media video pebelajaran diuji cobakan pada audien yaitu siswa kelan IV SDN Sukoiber 1 sebanyak 23 siswa.

Kegiatan uji coba dimulai dengan menampilkan media video pembelajaran materi Gaya dan selanjutnya dibagikan angket kepada siswa untuk mengukur kevalidan dan mengetahui pendapat siswa mengenai media video pembelajaran materi Gaya. Siswa juga diberikan pre-test dan post-test untuk mengukur efektivitas media dalam meningkatkan pemahaman materi Gaya.

\section{Evaluasi}

Pada tahap evaluasi yaitu membandingkan hasil yang diperoleh pada tahap uji coba siswa, ahli media, dan ahli materi media video pembelajaran materi Gaya. Juga menganalisis data yang didapat dari siswa untuk mengetahui pendapat/respon mengenai produk yang dibuat.

\section{HASIL}

Validasi media video pembelajaran dilakukan oleh ahli media, ahli materi dan uji coba siswa dan untuk mengukur kevalidan dan efektivitas media untuk meningkatkan pemahaman materi menggunkan tes.

Validasi ahli media, keseluruhan hasil data validasi diperoleh skor 75 dengan persentase 93,7\%. Berdasarkan kriteria dapat simpulkan media video pembelajaran materi Gaya dalam kriteria valid dan layak digunakan dalam pembelajaran.

Validasi ahli materi, keseluruhan hasil data validasi diperoleh skor 79 dengan persentase 98,7\%. Berdasarkan kriteria dapat disimpulkan media video pembelajaran materi Gaya dalam kriteria valid dan layak digunakan dalam pembelajaran.

Hasil uji coba pada 23 siswa kelas IV SDN Sukoiber 1 keseluruhan diperoleh skor 1331 dengan persentase $96,4 \%$. Berdasarkan kriteria dapat disumpulkan media video pembelajaran materi Gaya dalam kriteria valid dan layak digunakan dalam pembelajaran.

Hasil pre-test dan post-test yang telah dilakukan oleh siswa terdapat peningkatan ratarata dari 75,65 menjadi 93,04. Diperoleh hasildari 23 siswa 20 siswa mengalami kenaikan nilai sedangkan 3 siswa dinyatakan belum meningkat. Keseluruhan diperoleh hasil sebesar $86,95 \%$. Berdasarkan kriteria dapat disumpulkan media video pembelajaran termasuk dalam kriteria efektif dapat meningkatkan pemahaman siswa terhadap materi Gaya.

Hasil peningkatan pemahaman materi Gaya sebesar 30\% dan berdasarkan data uji N-Gain diperoleh nilai gain sebesar 0,71. Berdasarkan kriteria yang telah ditetapkan dapat disimpulkan peningkatan pemahaman materi Gaya tergolong Tinggi.

\section{PEMBAHASAN}

Media dapat diartikan sebagai perantara, guru dapat dapat menggunakan media untuk menyampaikan materi kepada siswa. Media video pembelajaran dipilih karena guru dapat mengoperasikan media dengan mudah walaupun belum pernah menggunakan media. Pemilihan media video berdasarkan kesesuaian dengan tujuan pembelajaran dan media video sangat disenangi oleh siswa.

Media video pembelajaran materi Gaya yang dikembangkan memuat teks, gambar, audio, dan animasi. Media video pembelajaran materi Gaya yang dikembangkan dari hasil validasi oleh ahli media sebesar $93,7 \%$, ahli materi sebesar $98,7 \%$ dan uji coba sebesar $96,4 \%$ diperolehan hasil validasi tersebut media video pembelajaran materi Gaya valid dan layak digunakan dalam proses pembelajaran. 
Terdapat dua teori yang melandasi efektivitas media video (Hadi, 2017) yaitu teori Edgar Dale dan teori Brunner. Kedua teori tersebut menegaskan bahwa pengalaman belajar yang bermakna akan diperoleh siswa ketika siswa belajar menggunakan semua panca indera. Dalam penelitiannya (Berk, 2009) menjelaskan bahwa belajar menggunakan media bergambar (video dan audio visual) lebih baik dari pada belajar dalam kondisi verbal (audio). Multimedia dapat merangsang pendengaran (verbal) dan pengliatan (visual) dalam meningkatkan pemahaman yang lebih dalam. Dari beberapa toeri dijelaskan bahwa lebih dari satu panca indera yang digunakan siswa ketika belajar, maka materi dapat lebih mudah diserap ketika proses belajar.

Media video dapat dioperasikan dengan mudah dan dapat diulang sehingga dapat mempermudah siswa memahami materi. Selain itu media video juga dapat menampilkan sebuah demonstrasi yang sulit diperagakan oleh guru (Arief, 2010). Dari kelebihan tersebut media penggunaan dan pemanfaatan media video dalam pembelajaran mampu meningkatkan pemahaman materi. Semakin banyak panca indera yang digunakan siswa ketika belajar, maka materi akan lebih mudah diserap ketika proses belajar. Belajar dengan menggunakan media video siswa memperoleh informasi dari indera pengliatan dan indera pendengar.

Hasil uji coba media video pembelajaran materi Gaya di SDN Sukoiber 1 dengan menggunakan pre-tes dan post-tes diperoleh hasil dari 23 siswa kelas IV 3 siswa belum megalami kenaikan nilai dan 20 siswa mengalami kenaikan nilai atau $86,95 \%$ siswa mengalami kenaikan nilai. Untuk melihat kenaikan pemahaman siswa dihitung menggunakan N-Gain dan diperoleh hasil, kenaikan pemahaman siswa $30 \%$ dan N-Gain sebesar 0,71. Dari hasil tersebut dapat disimulkan media video pembelajran materi Gaya efektif untuk meningkatkan pemahaman siswa.

\section{SIMPULAN}

Media video pembelajaran IPA materi Gaya kelas IV Sekolah Dasar memiliki kedudukan sebagai suplemen (tambahan) dalam proses pembelajaran. Media video pemebelajaran IPA untuk meningkatkan pemahaman materi Gaya berdasarkan tujuan penelitian pengembangan, media video pembelajaran memenuhi kriteria valid. Artinya, media video pembelajaran yang dikembangkan layak dan efektif mampu meningkatkan pemahanan siswa serta dapat digunakan dalam proses pembelajaran.

\section{DAFTAR RUJUKAN}

Abidin, Z., 2017. Penerapan Pemilihan Media Pembelajaran. Edcomtech J. Kaji. Teknol. Pendidik. $1 . \quad$ Dari http://journal2.um.ac.id/index.php/edcomtech/a rticle/view/1784

Aceto, S., Borotis, S., Devine, J., Fischer, T., 2014. Mapping and analysing prospective technologies for learning. Results Consult. Eur. Stakehold. Roadmaps Policy Action Luxemb. Publ. Off. Eur. Union. Dari https://ideas.repec.org/p/ipt/iptwpa/jrc88469.ht $\underline{\mathrm{ml}}$

Akbar, S., A’yun, I.Q., Satriyani, F.Y., Widodo, W., Paranimmita, R., Ferisa, D., (2016). Implementasi Pembelajaran Tematik di Sekolah Dasar. Bdg. Remaja Rosdakarya.

Arief, S., (2010). Media pendidikan. Jkt. PT Raja Graf.

Berk, R.A., 2009. Multimedia teaching with video clips: TV, movies, YouTube, and mtvU in the college classroom. Int. J. Technol. Teach. Learn. 5.5 Dari https://www.researchgate.net/profile/Ronald B erk/publication/228349436 Multimedia Teach ing with_Video_Clips_TV_Movies_YouTube and $\mathrm{mtvU}$ in the College Classroom/links/ 00b7d529cc691422b0000000/MultimediaTeaching-with-Video-Clips-TV-MoviesYouTube-and-mtvU-in-the-CollegeClassroom.pdf

Bonk, C.J., Graham, C.R., (2012). The handbook of blended learning: Global perspectives, local designs. John Wiley \& Sons.

Desstya, A. 2014. kedudukan dan aplikasi pendidikan sains di Sekolah Dasar. Profesi Pendidikan Dasar, 2(1), 193-200.

Fadhli, M. 2016. Pengembangan media pembelajaran berbasis video kelas IV Sekolah Dasar. Jurnal Dimensi Pendidikan dan Pembelajaran, 3(1), 24-33.

Gunawan, I., \& Palupi, A. R. (2016). Taksonomi Bloom-revisi ranah kognitif: kerangka landasan untuk pembelajaran, pengajaran, dan penilaian. Premiere educandum: jurnal pendidikan dasar dan pembelajaran, 2(02). Dari http://ejournal.unipma.ac.id/index.php/PE/article/view $\underline{150 / 47}$ 
50 JINOTEP (Jurnal Inovasi dan Teknologi Pembelajaran): Kajian dan Riset dalam Teknologi Pembelajaran Vol. 6, No. 1, Oktober 2019, Hal. 45-50

Hadi, S., 2017. Efektivitas Penggunaan Video Sebagai Media Pembelajaran Untuk Siswa Sekolah Dasar, in: Seminar Nasional Teknologi Pembelajaran Dan Pendidikan Dasar 2017. pp. 96-102.

Dari

http://pasca.um.ac.id/conferences/index.php/snt epnpdas/article/view/849

Ibda, F., 2015. Perkembangan kognitif: teori jean piaget. Intelektualita $\quad 3 . \quad$ Dari https://www.jurnal.arraniry.ac.id/index.php/intel/article/view/197

Passe, J., (1999). Elementary school curriculum. McGraw-Hill College.

Praherdhiono, H., 2016. Standar Program Pengukuran Kenyamanan Lingkungan Belajar Berbasis Ergonomi. Disertasi Dan TESIS Program Pascasarj. UM.
Praherdhiono, H., 2014. Convenience of Learning Environment for Student Special Education With Cyberwellness Concept. Proceeding International postdraduate University Kebangsaan Malaysia. SEAMOSEN.

Riyana, C., (2007). Pedoman pengembangan media video. Jakarta. P3ai UPI.

Tegeh, I.M., Jampel, I.N., Pudjawan, K., (2014). Model penelitian pengembangan. Yogyakarta. Graha Ilmu.

Widiyatmoko, A., Shimizu, K., 2018. An overview of conceptual understanding in science education curriculum in Indonesia, in: Journal of Physics: Conference Series. IOP Publishing, p. 012044. Dari https://iopscience.iop.org/article/10.1088/1742$\underline{6596 / 983 / 1 / 012044 / \mathrm{meta}}$ 